\title{
A case study: what is leached from mallee biochars as a function of $\mathrm{pH}$ ?
}

\author{
Caroline Lievens (iD - Daniel Mourant • Xun Hu • \\ Yi Wang • Liping Wu • Angelina Rossiter • \\ Richard Gunawan • Min He • Chun-Zhu Li
}

Received: 20 July 2017 / Accepted: 8 April 2018 / Published online: 18 April 2018

(C) The Author(s) 2018

\begin{abstract}
Biochar is widely considered as a soil amendment. This study aims to investigate the leaching of macronutrients $(\mathrm{K}, \mathrm{Mg}$ and $\mathrm{Ca})$ and organics from biochars produced from mallee biomass (wood, leaf, bark) in a fluidised-bed pyrolyser at $500{ }^{\circ} \mathrm{C}$. Biochars were soaked in solutions of varying $\mathrm{pH}$ values and shaken for a pre-set period of time ranging from $1 \mathrm{~h}$ to 4 weeks. The initial $\mathrm{pH}$ values of the leaching solutions used (3.4, 5.5, 7 and 8.5) covered the $\mathrm{pH}$ range of the soils in the Wheatbelt region of Western Australia (WA). For these bark, leaf and wood biochars, we can conclude that the biochars have a liming capacity for the acid soils of the WA Wheatbelt, depending on the feedstock. The maximum leachabilities and leaching kinetics of the macronutrients $\mathrm{K}, \mathrm{Mg}$ and $\mathrm{Ca}$ depend on the $\mathrm{pH}$ of the solution in which biochar was soaked. Apparently, $\mathrm{Ca}, \mathrm{K}$ and $\mathrm{Mg}$ in biomass are converted into different species upon pyrolysis, and the biomass species are critical for the extent of the leachability of macronutrients. Further, the chemical form of each nutrient retained in the biochars will dictate the kinetics as a function of soil $\mathrm{pH}$. This study's GC/MS analysis of solvent extraction of the biochars showed potential toxicity due to the leaching of light organic compounds when biochars are added to soils. Furthermore, this study also showed the influence of $\mathrm{pH}$ on the leaching of large aromatic organics from the biochars. Apart from the $\mathrm{pH}$ of leaching solution, the
\end{abstract}

C. Lievens $(\varangle) \cdot$ D. Mourant $\cdot$ X. Hu $\cdot$ Y. Wang $\cdot$ L. Wu $\cdot$

A. Rossiter $\cdot$ R. Gunawan $\cdot$ M. He $\cdot$ C.-Z. Li

Fuel and Energy Technology Institute, Curtin University, GPO

Box U1987, Perth, WA 6845, Australia

e-mail: c.lievens@utwente.nl influence of the biomass feedstock on the leaching kinetics of large aromatic organics from biochars was demonstrated. These leached aromatic organics were characterised by UV-fluorescence spectroscopy.

Keywords Biochar $\cdot$ Leaching $\cdot \mathrm{pH} \cdot$ Macronutrients · ICP-OES · GC-MS · UV-fluorescence · Mallee

\section{Introduction}

The application of biochars as an amendment for poor soils is receiving an increased consideration worldwide, at least partly due to the pressures to reduce the emission of greenhouse gases. The potential of biochar for soil conditioning, such as reducing soil acidity, improving soil cation exchange capacity, soil $\mathrm{pH}$, soil nutrient retention, water holding capacity and soil microbial habitat, makes biochar application an interesting option for increasing soil productivity and profitability (AbdelFattah et al. 2015; Lehmann 2007; Lehmann and Joseph 2009; Lehmann et al. 2011; Uchimiya et al. 2010, 2011).

The pyrolysis of different feedstocks (Lievens et al. 2008, 2015) under widely different conditions, such as temperature (Hagner et al. 2016; Lievens et al. 2009), would result in a large variety of biochars, all with specific characteristics in regard to inorganic compositions. Some biochars are known to sorb organic (Buss et al. 2016; Mohan et al. 2014) and inorganic molecules (Silber et al. 2010; Velghe et al. 2012), retaining nutrients against leaching losses. These are all important factors in improving crop productivity and soil fertility. 
The release of nutrients from biochar, especially inorganic nutrients, would depend on the $\mathrm{pH}$ of moisture (water) in the soil (Randolph et al. 2017). The department of Agriculture and Food of Western Australia (WA) found that the $\mathrm{pH}$ of topsoils in the WA Wheatbelt ranges between 3.8 and 8.1 , with $80 \%$ of the topsoils falling below the critical surface $\mathrm{pH}_{\mathrm{CaCl} 2}$ of 5.5 (Gazey and Andrew 2009). Little is known about the effects of biochar addition to the soils, including potential toxic effects to the soil, as a function of the soil $\mathrm{pH}$.

Previous studies have demonstrated that organics can be leached from biochars when in contact with water (Hartley et al. 2016; Lievens et al. 2015). The addition of biochar to soil could have potential toxic effects due to the leaching of organics. For example, during the biomass pyrolysis for biochar production, some of the organic-based tars may condense on the biochars' surface, making it vital to understand the leachability of organic matter in biochars when they come in contact with water. Soils can have different $\mathrm{pH}$ and the leaching of organics could be $\mathrm{pH}$ dependent. The identification and characterisation of organic matter leached out should also be understood as such information is essential in assessing the toxicity of the leached-out organic matter to the soils and its biota. Little to no such data exists; no experiments have been performed to investigate the leachability of organic compounds, as a function of soil $\mathrm{pH}$, from biochars to our knowledge. Pyroligneous acid (pyrolysis liquids) has been added to soils, used to control pests and diseases (Focht 1999). It has been illustrated that when bio-oils are added to soils, that these pyrolysis compounds are easily metabolised by soil microbes and bacteria, and even intensify the respiratory metabolism of the soils (Fischer and Bienkowski 1998; Steiner et al. 2008). However, some of the typical biomass pyrolysis liquid compounds, e.g. phenols, have been on the list of priority pollutants for a long time, due to their potential to cause many adverse effects to human health and the environment (Djokic et al. 2013). Concentrations as low as $0.005 \mathrm{mg} \mathrm{l}^{-1}$ are causing adverse effects to aquatic environment, while $0.8 \mathrm{mg} \mathrm{kg}$ of soil ${ }^{-1}$ is considered toxic (Djokic et al. 2013).

Mallee was used in this study since mallee eucalypt is a small, multi-stemmed tree that is currently grown on marginal land, but also grown in the Wheatbelt of WA as a way to control soil salinity and offer protection to crops. It can be harvested every few years and the tree resprouts from the cut stump; in essence, mallee wood is in abundance, hence much biochar can be produced locally. A distinction between wood, leaf and bark needs to be made since they have different anatomical features (Lievens et al. 2011), making the distribution of macronutrients different depending on the plant part. This is because some of these elements prefer to reside in water-rich tissues or are central to chlorophyll (Ghisalberti 1996; Kramer and Kozlowski 1979). The hypothesis is that pyrolysis of different plant parts will result in different biochars with different forms of macronutrients which will behave differently when soil solution $\mathrm{pH}$ is altered.

In this study, we investigated the potential toxicity due to light bio-oil compounds leaching from bark, leaf and wood biochars, in which the biochars were solvent washed after which the leachates were GC/MS analysed for light bio-oil compounds. Further, the leaching of macronutrients $(\mathrm{Ca}, \mathrm{K}, \mathrm{Mg})$ and aromatic organics from the respective biochars as a function of the $\mathrm{pH}$ of the leaching solution and time was investigated. To exclude all other soil parameters, except $\mathrm{pH}$, a simple set-up was devised in which biochars were stirred in certain $\mathrm{pH}$ solutions. Four $\mathrm{pH}$ buffer solutions were prepared: 3.4, $5.5,7$ and 8.5 , covering the whole range of soil $\mathrm{pH}$ of the WA Wheatbelt. The influence of $\mathrm{pH}$ was investigated in regards of the nature, concentration and kinetics of leached inorganic compounds from biochars originating from the three feedstocks. The released aromatic organics were characterised by UV-fluorescence spectroscopy.

\section{Experimental section}

Preparation of biochars

Biochars were produced from the pyrolysis of mallee bark, leaf and wood in a fluidised-bed pyrolyser. The bark, leaf and wood biochars (Eucalyptus loxophleba ssp. gratiae, 180-600 $\mu \mathrm{m}$ particle size) were produced at $500{ }^{\circ} \mathrm{C}$. The residence time of the solids of biomass/ biochar during pyrolysis was both $1.4 \mathrm{~s}$ in the reactor for $500{ }^{\circ} \mathrm{C}$. The detailed description of the pyrolyser and the various experiments can be found elsewhere (GarciaPerez et al. 2008; He et al. 2012; Mourant et al. 2013).

\section{Leaching experiments}

Biochars were immersed and shaken in solutions (biochar/solution ratio of 1:20 by weight) of $\mathrm{pH} 3.4,5.5,7$ and 8.5. After the pre-set soaking time ( $1 \mathrm{~h}, 1$ day, 1 week, 2 weeks or 4 weeks) was elapsed, the solutions 
were filtered through a $0.2-\mu \mathrm{m}$ Supor® membrane filter. After filtration, the biochar wash solutions were kept in a refrigerator $\left(4^{\circ} \mathrm{C}\right)$. The various buffers, with their buffering capacity, used to maintain the required solution $\mathrm{pH}$ are described in Table 1. All leaching experiments were performed in duplicate.

Characterisation of biochars: proximate and ultimate analyses

The ash yield (CEN 14775) and moisture content (CEN 14774) of biochars were determined by an external laboratory according to the European standards. Carbon, hydrogen and nitrogen were determined using a Leco Truspec Analyser.

The total elemental concentrations of $\mathrm{K}, \mathrm{Ca}, \mathrm{Mg}$ in biochars were determined after the acid digestion of the biochars. For the acid digestion, $50 \mathrm{mg}$ of biochars was weighed in small Pyrex beakers covered with Pyrex watch glasses. To each biochar sample, $2 \mathrm{~mL}$ of $\mathrm{HNO}_{3}$ (69\%, Suprapur, Merck) was added and was then heated to a temperature of approximately $150-175^{\circ} \mathrm{C}$ in a fume cupboard. After the nitrous gases had dissipated, the beakers were rinsed with ultrapure water (Millipore water; $18.2 \mathrm{M} \Omega . \mathrm{cm}$ ). After the evaporation of water, more nitric acid was added and the procedure was repeated, during which the biochars became more and more digested and the digestion solutions changed colour from brown, brownish red, dark red, orange to yellow. For the more resilient biochars, where the acid digestion solutions remained dark in colour even after $\mathrm{HNO}_{3}$ had been added repeatedly, $\mathrm{HClO}_{4}(70 \%$, redistilled, Aldrich) was added. $\mathrm{HClO}_{4}$ was always added as a mixture: $\mathrm{HNO}_{3}-\mathrm{HClO}_{4}$ (4:1) (Bock 1979). After the digestion was completed, the dry yellowish residues in the beakers were dissolved in ultrapure water.

Table 1 Buffer solutions used for the leaching of biochars at different $\mathrm{pH}$ levels

\begin{tabular}{|c|c|c|}
\hline $\begin{array}{l}\text { Determined } \\
\mathrm{pH}\end{array}$ & $\mathrm{pH}$ buffer solutions & $\begin{array}{l}\text { Buffering } \\
\text { capacity }\end{array}$ \\
\hline 3.4 & $\begin{array}{c}500 \mathrm{~mL} 0.2 \mathrm{M} \text { glycine }-50 \mathrm{~mL} \\
0.2 \mathrm{M} \mathrm{HCl} \text {, diluted to } 1 \mathrm{~L}\end{array}$ & $2.2-3.6$ \\
\hline 5.5 & $\begin{array}{l}95 \mathrm{~mL} 0.1 \mathrm{M} \text { acetic acid- }-905 \mathrm{~mL} \\
0.1 \mathrm{M} \text { sodium acetate }\end{array}$ & $3.7-5.6$ \\
\hline 7 & $\begin{array}{l}500 \mathrm{~mL} \mathrm{0.1} \mathrm{M} \mathrm{NaH} \mathrm{PO}_{4}-300 \mathrm{~mL} \\
0.1 \mathrm{M} \mathrm{NaOH}\end{array}$ & $5.8-8.0$ \\
\hline 8.5 & $\begin{array}{l}500 \mathrm{~mL} 0.2 \mathrm{M} \text { glycine- }-80 \mathrm{~mL} 0.1 \mathrm{M} \\
\mathrm{NaOH} \text {, diluted up to } 1 \mathrm{~L}\end{array}$ & $8.4-10.6$ \\
\hline
\end{tabular}

Following this process, the solutions were analysed with ICP/OES. All digestions were performed in duplicate, and the results were corrected with blank experiments.

GC/MS analysis of leachate from leaching biochars with organic solvent

The biochars were washed with methanol (LC Chromasolv, HPLC quality of Merck) or methanol/ chloroform (HPLC quality of Merck) for $72 \mathrm{~h}$ (biochar/solution ratio of 15:100). After the stirring time had lapsed, the solutions were filtered over a $0.2-\mu \mathrm{m}$ Supor ${ }^{\circledR}$ membrane filter. The analysis of the compounds in the biochar leaching solutions was carried out using an Agilent GC-MS (6890 series GC with 5973 series MS detector), with a $30 \mathrm{~m} \times 0.25 \mathrm{~mm}$ i.d HP-Innowax capillary column $(0.25 \mu \mathrm{m}$ cross-linked polyethylene glycol). The analysis consisted of injecting $1 \mu \mathrm{L}$ of sample under the following conditions: splitless, initial oven temperature of $40{ }^{\circ} \mathrm{C}$ with a holding period of $3 \mathrm{~min}$, then heated at a heating rate of $10{ }^{\circ} \mathrm{C} \mathrm{min}{ }^{-1}$ to $260{ }^{\circ} \mathrm{C}$ and held for $5 \mathrm{~min}$. A solvent delay of 3.6 min was employed. Masses were scanned from 15 to 500 mass units. The identification of each compound was achieved by the match of its mass spectrum with that in the spectral library and was further confirmed by injecting the standard when available. Standard solutions were used to obtain the calibration curves to calculate the concentrations of the compounds of interest. It was difficult to obtain standards for all the compounds identified in the GC-MS chromatograms. In those cases, the signal intensity (peak area) of the compound was used as a measure of the changes in their concentration as a function of reaction conditions.

Analysis of leachates from the leaching of biochars

\section{$p H$}

The $\mathrm{pH}$ of the buffer solutions and biochar leachates was measured using a TPS smart Chem-Lab Laboratory analyser with a combination $\mathrm{pH}$ sensor.

\section{ICP/OES}

The nutrients (Ca, $\mathrm{Mg}, \mathrm{K}$ ) in the biochars (after digestion) and those leached from the biochars were determined with a Perkin Elmer Optima 7300 DV (Dual View) $\mathrm{ICP} / \mathrm{OES}$. $\mathrm{Ca}, \mathrm{Mg}$ and $\mathrm{K}$ were all measured using a 
normal purge method. Magnesium and calcium were measured axially, potassium radially, to avoid the underestimation of $\mathrm{K}$ as a result of recombination of ions and electrons in the plasma. Calibration was performed by diluting a 10,000-mg/L Merck ICP/MS standard solution.

\section{Analysis of leachates from the leaching of biochars with UV-fluorescence}

In this study, the UV-fluorescence spectra of biochar leaching solutions with an initial $\mathrm{pH}$ value of 3.4, 5.5, 7 and $\mathrm{pH} 8.5$ were recorded using a Perkin-Elmer LS50B spectrometer. The obtained biochar wash samples were diluted with ultrapure water to obtain a linear relationship between UV fluorescence intensity and concentration. The synchronous spectra were recorded with a constant energy difference of $-2800 \mathrm{~cm}^{-1}$. The slit widths were $2.5 \mathrm{~nm}$ and the scan speed was $200 \mathrm{~nm} \mathrm{~min}{ }^{-1}$. The "wavelength" shown for each spectrum refers to that of the excitation monochromator. Wavelength is a brief indication of the aromatic ring systems (Li et al. 1993; Wang et al. 2012) although a clear delineation about size of aromatic ring systems and wavelength ranges is impossible. Intensities shown are averages of duplicate experiments. At the same concentration, the fluorescence intensity was divided by the amount of char to express all fluorescence intensity on the basis of "per gram of char".

\section{Results and discussion}

\section{Characteristics of biochars}

Table 2 gives the proximate and elemental analyses of the biochars produced in the fluidised-bed pyrolyser. Wood biochar had lower ash yield and oxygen content than other biochars produced under similar conditions. All $\mathrm{C} / \mathrm{N}$ ratios were above the critical limit of 20 , the limit above which the immobilisation of $\mathrm{N}$ by microorganisms occurs and nitrogen is no longer available to plants (Lehmann and Joseph 2009). In essence, mallee bark, leaf and wood biochars are a poor choice for soil $\mathrm{N}$-replenishment if used as is.

Table 3 gives the elemental analyses of the biochars produced in the fluidised-bed pyrolyser, as are the respective yields of bark, leaf and wood biochars. It is very clear from Table 3 that biochar of wood had the lowest concentrations of $\mathrm{Ca}, \mathrm{Mg}$ and $\mathrm{K}$, which are
Table 2 Proximate and elemental analyses of biochars used in this study

\begin{tabular}{llll}
\hline Feedstock & Bark & Leaf & Wood \\
\hline Moisture (\%) & 6.1 & 6.2 & 3.75 \\
Ash (\% db) & 25.1 & 20.9 & 15.15 \\
$\mathrm{C}(\%$ daf) & 76.9 & 81.2 & 85.9 \\
$\mathrm{H}(\%$ daf) & 2.9 & 3.2 & 6.5 \\
$\mathrm{~N}(\%$ daf) & 0.3 & 2.3 & 0.2 \\
$\mathrm{O}$ (\% daf) & 20.0 & 13.5 & 7.4 \\
$\mathrm{C} / \mathrm{N}$ & 428 & 43 & 669 \\
$\mathrm{H} / \mathrm{C}$ & 0.46 & 0.47 & 0.49 \\
$\mathrm{O} / \mathrm{C}$ & 0.19 & 0.12 & 0.06 \\
\hline
\end{tabular}

${ }^{\mathrm{a}}$ Oxygen \% (by difference)

macronutrients for plants, among all biochars investigated in this study. The loss of macronutrients upon pyrolysis depends on the biomass feedstock. Apparently, $\mathrm{Ca}, \mathrm{Mg}$ and $\mathrm{K}$ in leaf biomass are concentrated in the biochar without apparent loss. Macronutrient $\mathrm{Ca}$ in bark and wood, however, is partly lost during pyrolysis, as is potassium after wood pyrolysis.

Light organic compounds leached out from biochar using organic solvents

Bark and wood biochars were washed with methanol, leaf biochars with methanol/chloroform, which is known to be a very effective mixture, better than methanol and/or acetone, to dissolve the leaf pyrolysis biooils. GC/MS analysis was performed to obtain information about the bio-oil compounds condensed on mallee biochars. These results give information about the light bio-oil fraction that has been condensed on mallee biochars during the fast pyrolysis process. They also indicate the possible toxicity of biochars when added to the soil due to the leaching of these physically adhering biooil compounds. No information about possible condensed large multi-fused aromatic structures were obtained since these compounds have very high boiling points, which are not detected in the GC/MS. All major GC/MS-detected compounds in the methanol or methanol/chloroform leachates of bark, leaf and wood biochars have been quantified. Table 4 lists the concentrations of these compounds, expressed as $\mu \mathrm{g} / \mathrm{g}$ of biochar or peak area/g of biochar.

The results in Table 4 show that compounds physically adhered to the biochar were very dependent on the 
Table 3 Macronutrient concentrations $\left(\mathrm{mg} / \mathrm{kg}\right.$ ) in the biomass and biochars (produced at $500{ }^{\circ} \mathrm{C}$ ) prepared in a fluidised-bed pyrolysis reactor and the yields of the biochars

\begin{tabular}{|c|c|c|c|c|c|c|}
\hline & Bark & $500{ }^{\circ} \mathrm{C}$ & Leaf & $500{ }^{\circ} \mathrm{C}$ & Wood & $500{ }^{\circ} \mathrm{C}$ \\
\hline $\mathrm{K}$ & $2176 \pm 132$ & $6920 \pm 50$ & $3865 \pm 310$ & $17,000 \pm 130$ & $1095 \pm 70$ & $4700 \pm 111$ \\
\hline $\mathrm{Ca}$ & $33,905 \pm 2650$ & $56,400 \pm 90$ & $5949 \pm 271$ & $26,300 \pm 100$ & $2490 \pm 150$ & $13,200 \pm 190$ \\
\hline $\mathrm{Mg}$ & $1094 \pm 58$ & $3040 \pm 40$ & $1194 \pm 56$ & $4800 \pm 20$ & $355 \pm 20$ & $1920 \pm 1$ \\
\hline Char Yields & & $33 \%$ & & $27 \%$ & & $15 \%$ \\
\hline
\end{tabular}

Errors shown represent the standard deviations of determinations

feedstock from which they originated. For example, furfural (and derivates) and acetic acid were detected in much higher concentrations in the wood biochar leachate than the bark and leaf leachates. Furfural is formed by dehydration of the xylose unit (hemicellulose component) (Demirbas 2005). The formation of acetic acid results from the elimination of acetyl groups originally linked to the xylose unit (Matsuzawa et al. 2001) or after dehydration and decarbonylation of cellulose (Demirbas 2001). Taking a closer look at the chemical build-up of the different mallee plant parts, it is clear that the differences in concentrations in furfural and acetic acid in the biochar leachates can be found from the variation in concentrations of hemi-cellulose/ cellulose in the feedstock. In particular, the wood fraction of mallee contains $63 \%$ of hemi-cellulose/cellulose, far more than the leaf (30\%) and bark (46\%) fraction of the same mallee trees (Lievens et al. 2011).

Two possible explanations may be given for detecting bio-oil compounds in the char fraction. The short particle residence time in the fluidized-bed reactor, at the order of seconds, may not be long enough for the pyrolysis reactions to go to completion and/or for the pyrolysis products to be transferred out of the particles. The second possibility is that these compounds listed in Table 4 have their origin from the re-condensation of bio-oil vapours before the bio-oil vapour and biochar were separated.

Comparing the light bio-oil compounds that adhered on the mallee biochars (Table 4), a variety of compounds with higher concentrations adhered to wood biochar surfaces. These data indicate that wood behaved

Table 4 All major GC/MS identified compounds ( $\mu \mathrm{g} / \mathrm{g}$ char or area/g char) in the solutions after leaching the biochars with solvents

\begin{tabular}{|c|c|c|c|}
\hline & $\begin{array}{l}\text { Bark } \mu \mathrm{g} / \mathrm{g} \text { char } \\
\text { (methanol leaching) }\end{array}$ & $\begin{array}{l}\text { Leaf } \mu \mathrm{g} / \mathrm{g} \text { char } \\
\text { (methanol leaching) }\end{array}$ & $\begin{array}{l}\text { Wood } \mu \mathrm{g} / \mathrm{g} \text { char } \\
\text { (methanol leaching) }\end{array}$ \\
\hline Phenol & 8.5 & 16 & 52 \\
\hline Levoglucosan & 58 & 75 & 350 \\
\hline Compound & Area/g biochar & & \\
\hline Acetic acid & 82,400 & 206,000 & $10,880,000$ \\
\hline Furfural & n.d. & n.d. & $2,604,000$ \\
\hline Propanoic acid & n.d. & n.d. & 883,000 \\
\hline Glycol & n.d. & n.d. & $2,271,000$ \\
\hline 3-methyl butanoic acid & n.d. & 33,000 & n.d. \\
\hline Cylcopentene & n.d. & n.d. & 88,700 \\
\hline 4-Methoxyphenol & 3870 & n.d. & n.d. \\
\hline 3,4-Dimethoxyphenol & 4120 & 70,000 & $1,834,000$ \\
\hline 1,2,4-Trimethoxybenzene & n.d. & 26,000 & 403,000 \\
\hline OHmethylfurfural & n.d. & n.d. & 185,000 \\
\hline 4-OH-3-methoxybenzaldehyde & n.d. & 16,100 & 339,000 \\
\hline
\end{tabular}

n.d. not detected 
differently from bark and leaf under the same pyrolysis conditions. Having experienced higher weight losses, the wood biochar may be more porous than those of leaves and bark, giving rise to better adsorption characteristics (He et al. 2012; Mourant et al. 2011, 2013). Alternatively, the bio-oil vapours from the wood biochar contained higher concentrations than those species listed in Table 4, giving better chance for them to be physically adhered to char in comparison to bark and leaves biochar.

The phenolic compounds leached out of mallee biochars listed in Table 4 are on the priority list of hazardous substances (Djokic et al. 2013). These compounds could cause environmental concerns when maximum concentrations are reached in soil or groundwater. Concentrations as low as $0.005 \mathrm{mg} \mathrm{l}^{-1}$ can cause adverse effects to an aquatic environment, while $0.8 \mathrm{mg} \mathrm{kg}$ of soil $^{-1}$ are considered toxic (Djokic et al. 2013). The concentration of phenol leached from bark, leaf and wood biochars with organic solvents range from 8 to $52 \mathrm{mg} / \mathrm{kg}$ biochar depending on the biochar species. These data serve to demonstrate further that the actual amounts of light species that are contained in biochar do vary with mallee source feedstock.

The exact possible toxicity of the (light) bio-oil compounds after the biochar has been applied to the soil would depend on many complicated factors. For example, surface adhering pyrolysis condensates, including water soluble compounds (e.g. carbonyls, alcohols and sugars), can easily be metabolised by soil microorganisms, as discussed intensely in literature (Fischer and Bienkowski 1998; Focht 1999; Steiner et al. 2008). Furthermore, the type of biochar or soil characteristics, soil $\mathrm{pH}$ and biota, also have an influence on the biodegradability of phenolics (Baker and Mayfield 1980). Fischer and Bienkowski (1998) investigated the toxicity and intensity of soil metabolism when exposed to aromatic hydrocarbons, such as benzenes, phenolics, furan derivates, naphthalene and numerous polycyclic aromatic hydrocarbons. All these compounds can be consumed by strains of prototrophic bacteria occurring in the soils, as these compounds can be used as food by soil organisms. The pyrolysis compounds appear to be a metabolizable substrate for the microbial community. The turnover time of these substrates is likely to be on the order of one to two seasons and will not determine community composition for any length of time (Lehmann and Joseph 2009), unless frequently reapplied.
Characterisation of leachates of biochars

\section{pH of the leachates}

Figure 1 depicts the evolution of $\mathrm{pH}$ value of leachates as a function of leaching time. For the buffer solutions with $\mathrm{pH}$ of 3.4, we saw a fast increase in $\mathrm{pH}$ reaching a $\mathrm{pH}$ of $>7$ after 1 week, illustrating the liming capacity of these biochars. In other words, the amounts of $\mathrm{K}, \mathrm{Mg}$ and $\mathrm{Ca}$ leached out from the biochars had far exceeded the buffering capacities of the buffer solutions used at the beginning of the leaching trials. In general, for all biochars, the $\mathrm{pH}$ increased when adding biochars to solutions, making the leachates alkaline, with the exception of the $\mathrm{pH} 5.5$ leachate of wood biochar, where the $\mathrm{pH}$ remained slightly acidic as a function of time. While the $\mathrm{pH}$ of the leachates of other two biochars could go well above 8 , the leachates from wood biochar were well below 8 under the experimental conditions investigated. The ability to change the $\mathrm{pH}$ of the leachates would be related to the ion-exchange ability of the biochars. However, organic compounds can be adsorbed to the surfaces of biochars (Lievens et al. 2015). As discussed earlier, the biochars adsorbed light organic compounds which could potentially be leached when biochars are added to soils. These leachates showed the leaching of acetic acid (Table 4), increasing the buffering effect of $\mathrm{pH}$ solutions. The potential leachable concentration of acetic acid was highest in wood biochar where the $\mathrm{pH}$ remained below 8 under the experimental conditions investigated.

These trends illustrate that the liming effects of biochars would change with the biomass feedstock properties. It should be pointed out that the changes in the $\mathrm{pH}$ of the leachates are related to both the amounts of macronutrients $(\mathrm{K}, \mathrm{Mg}$ and $\mathrm{Ca}$ ) as well as the pyrolysis liquids being leached out. Moreover, the changes in $\mathrm{pH}$ of the leachates is most likely linked the speciation of the macronutrients and the chemical forms of the nutrients in the biochars. For example, two $\mathrm{H}^{+}$would be required to ion exchange one divalent species $\left(\mathrm{Ca}^{2+}\right.$ and $\left.\mathrm{Mg}^{2+}\right)$ or two monovalent species $\left(\mathrm{K}^{+}\right)$in the biochar. The exact nature of functional groups in the biochars that bond macronutrients could also affect the $\mathrm{pH}$ of the resulting leachates. In order to better understand the leaching process of macronutrients, the overall leachability and the leaching kinetics were investigated. These are important information in terms of recycling of nutrients from biochar applied to the soil. 
Fig. 1 Changes in the $\mathrm{pH}$ of leachates as a function of leaching time during the leaching of biochars from the pyrolysis of wood, leaves and bark. The trend lines in all figures have simply connected the datum points and do not represent any model calculations
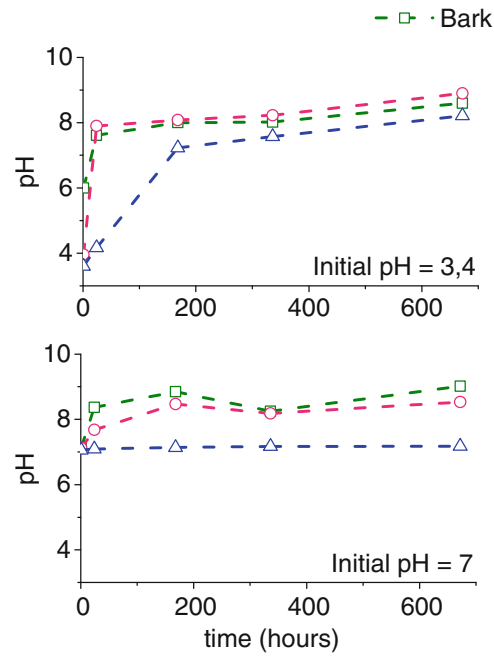

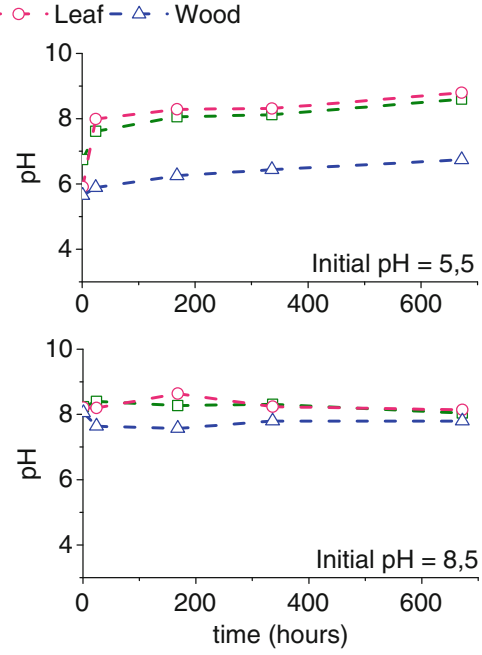

\section{Maximum leachability of elements - an overview of the leaching process}

Table 5 shows the maximum amounts of $\mathrm{K}, \mathrm{Ca}, \mathrm{Mg}$ in biochars, which have been leached out, under the conditions investigated, into the leaching solutions at different initial $\mathrm{pH}$ values, expressed as $\%$ of these elements found in the corresponding biochars before leaching.

The concentrations of these elements leached from biochars, within the leaching time investigated, were highly dependent on the $\mathrm{pH}$ of the leaching solution and biomass feedstock to prepare the biochars (Table 5). Potassium leaching characteristics are dominated by the biomass feedstock to prepare the biochars in the leaching solution since for wood biochars, almost maximum leachability is reached compared to leaf and bark biochars, and independent of the $\mathrm{pH}$ of the buffer solutions.

Table 5 Maximum percentages of $\mathrm{K}, \mathrm{Ca}, \mathrm{Mg}$ in biochars that have been leached at different initial $\mathrm{pH}$ values

\begin{tabular}{llllll}
\hline & & $\mathrm{pH} 3.4$ & $\mathrm{pH} \mathrm{5.5}$ & $\mathrm{pH} \mathrm{7}$ & $\mathrm{pH} \mathrm{8.5}$ \\
\hline Bark 500 ${ }^{\circ} \mathrm{C}$ & $\mathrm{K}(\%)$ & 77 & 91 & 88 & 72 \\
& $\mathrm{Ca}(\%)$ & 8 & 8 & 1 & 1 \\
& $\mathrm{Mg}(\%)$ & 18 & 18 & 6 & 9 \\
Leaf 500 ${ }^{\circ} \mathrm{C}$ & $\mathrm{K}(\%)$ & 86 & 82 & 89 & 73 \\
& $\mathrm{Ca}(\%)$ & 5 & 7 & 2 & 1 \\
Wood 500 ${ }^{\circ} \mathrm{C}$ & $\mathrm{K}(\%)$ & 100 & 100 & 100 & 83 \\
& $\mathrm{Ca}(\%)$ & 20 & 15 & 3 & 4 \\
& $\mathrm{Mg}(\%)$ & 17 & 14 & 12 & 7 \\
\hline
\end{tabular}

For calcium, the leachability is remarkably low in the $\mathrm{pH}$ buffer solutions under investigation. Apparently, pyrolysis rendered the bulk of calcium-macronutrient unavailable to the environment in which it is leached. $\mathrm{Ca}$, e.g. the majority could be present as carbonate as it becomes insoluble at $\mathrm{pH}>6.8$, as these $\mathrm{pH}$ values are found for most of the leaching buffer solutions (Fig. 1) in this research. Magnesium leachability seems independent of the biomass of which it originates. The speciation of $\mathrm{Mg}$ could not be determined. Speciation could be investigated with SEM-EDX; however, this technique was not available to us during the course of this particular set of experiments.

The change in leachability of macronutrients as a function of $\mathrm{pH}$ and biochar type gives a strong indication that these macronutrients are converted into different speciation upon pyrolysis.

These data provide an overview of the leaching process. While the $\mathrm{pH}$ value determined the concentration for $\mathrm{H}^{+}$that was available for ion-exchange and the biomass properties determined the chemical forms of the macronutrients in the biochars to be leached. The exact roles of each of these parameters would be better understood by considering the leaching kinetics in the next section.

\section{Leaching kinetics of elements}

Figure 2 illustrates the leaching profiles for $\mathrm{K}, \mathrm{Ca}$, $\mathrm{Mg}$ from bark, leaf and wood $\left(500^{\circ} \mathrm{C}\right)$ biochars. For the leaching of potassium, the total amounts of $\mathrm{K}$ leached out from biochar increased gradually with 
$\mathrm{pH} 3.4-4-\mathrm{pH} 5.5--\star-\mathrm{pH} 7--*-\mathrm{pH} 8.5$
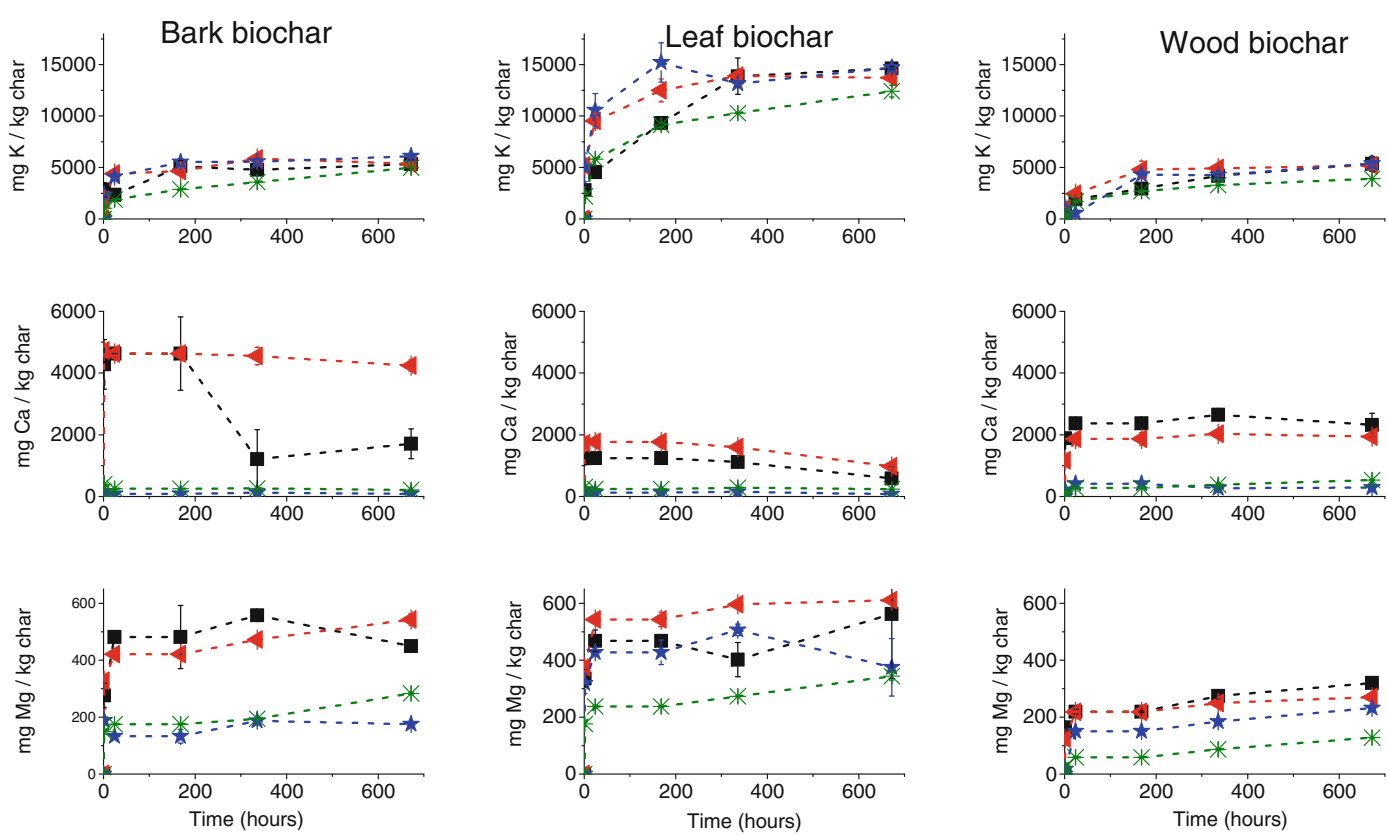

Fig. 2 Leaching kinetics of $\mathrm{K}, \mathrm{Ca}, \mathrm{Mg}\left(\mathrm{mg} / \mathrm{kg}\right.$ char) from $500{ }^{\circ} \mathrm{C}$ biochars at different initial $\mathrm{pH}$ values

time at all initial $\mathrm{pH}$ levels. The (initial) $\mathrm{pH}$ value played a role in the leaching rates, however small. It appears that the leaching rate generally decreased with increasing $\mathrm{pH}$ value. The leaching in the buffer having an initial $\mathrm{pH}$ of 8.5 was the slowest.

Calcium leaching kinetics in the buffer solutions having initial $\mathrm{pH}$ values of 7 and 8.5 followed very similar trends to those of $\mathrm{K}$. As is shown in Fig. 1, starting at $\mathrm{pH} 3.4$ and 5.5 for the leaching of bark and leaf biochar, the $\mathrm{pH}$ of the leaching solution for these biochars changed to above 7 after a week, to above 8 after 4 weeks. These systematic $\mathrm{pH}$ increases, to above 7 , could be responsible for the reduced calcium leaching after 1 week: a higher $\mathrm{pH}$ hindering the leaching of $\mathrm{Ca}$, including the possible formation of $\mathrm{Ca}$ precipitates such as $\mathrm{CaCO}_{3}$. For wood biochars in $\mathrm{pH} 5.5$ (initial) solutions, where the $\mathrm{pH}$ of leachate solution never reached $\mathrm{pH}$ of 7, the concentration of leached $\mathrm{Ca}$ does not decrease after 1 week.

The leaching of magnesium tended to be gradual for all $500{ }^{\circ} \mathrm{C}$ biochars. Alternatively, the leaching of $\mathrm{Mg}$ was more sensitive to $\mathrm{pH}$ than that of potassium. It appears that the leaching rate generally decreased with increasing $\mathrm{pH}$ value. The leaching in the buffer having an initial $\mathrm{pH}$ of 8.5 was the slowest.
Aromatic compounds leached out from biochar using buffer solutions

The data presented above on the leaching of biochars with organic solvents reflect broadly the upper limits of organics that might be leached out from the biochars. As can be clear from the preceding discussion, the possible toxicity of the leachates in soil would depend on the rates at which the organics are released from the biochar as well as the consumption rates of these compounds by various chemical and biological processes in the soil. In order to understand the leaching kinetics, i.e. the rates at which organics are released from biochar, the same leachates that were investigated for macronutrients were investigated for organic aromatic compounds.

Figure 3 shows the UV fluorescence spectra of the leaching solutions as a function of leaching time and leaching solution initial $\mathrm{pH}$ value. The fluorescence intensities are expressed on the basis of intensity per gram of biochar. The data are accumulative in nature, e.g. the organics in the leachate in 4 weeks included those of $1 \mathrm{~h}$. To make a better identification of the observed leachate biochar spectra, previous UVfluorescence studies of coals (Kashimura et al. 2004; Kershaw et al. 2000) and bio-oils (Oudenhoven et al. 2016) were used. Oudenhoven et al. (2016) studied 

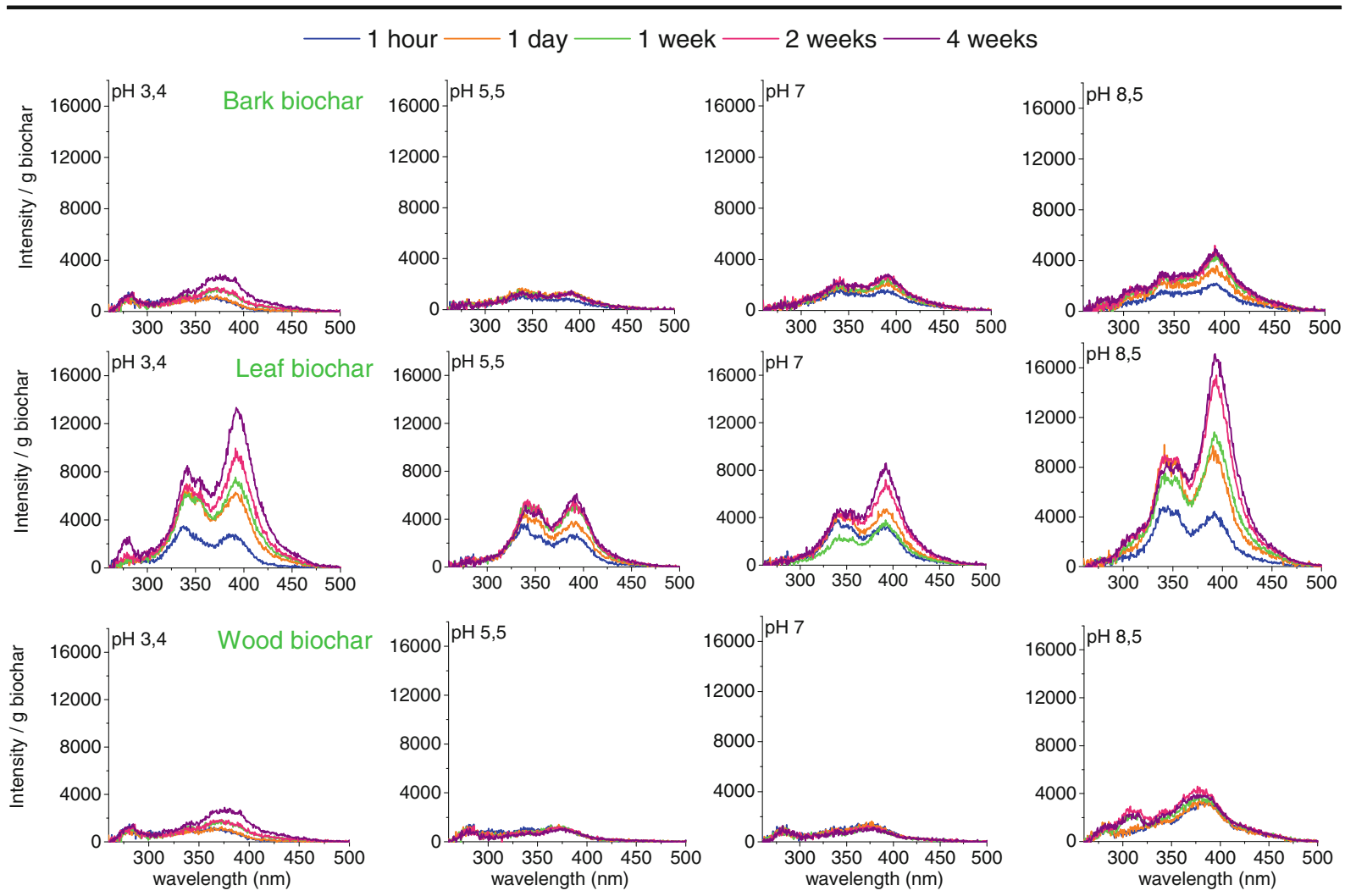

Fig. 3 UV fluorescence spectra of bark, leaf and wood $\left(500^{\circ} \mathrm{C}\right)$ biochar of the leaching solutions as a function of leaching time and initial $\mathrm{pH}$ value as indicated

(heavy) pyrolysis oils with UV-fluorescence. To identify the compounds in the spectra, model compounds were investigated and showed that phenolics can be detected between wavelengths of 250-300 nm, naphtol, methoxy naphthalene between 290 and $330 \mathrm{~nm}$, fluoranthene between 350 and $400 \mathrm{~nm}$. The intensity of the observed UV-fluorescence bands is also determined by the polarity of the molecule, e.g. same concentration of naphalene and naphtol, naphtol gives an intensity 5 times higher. Basically, the higher the number of aromatic rings in the compounds, the higher the wavelength at which they give a signal/response.

For all leaching solutions investigated, the leaf biochars gave much higher fluorescence intensity than the wood and bark biochars. The high intensity is either a measure for the concentration and/or polarity of the leached compounds. Hence, leaf biochar when in contact with water like solutions leached out the highest concentration of complex aromatic compounds or the most polar compounds. Further, the UV fluorescence intensity of each leachate seemed to be determined by the $\mathrm{pH}$ of the initial solution, as high intensities were found for leachates with an initial $\mathrm{pH}$ of 8.5. However, the $\mathrm{pH}$ of each of the leaf leachates is above 8 after 4 weeks, seems to indicate that the buffering agents (Table 1) have a bigger effect on the leachability of complex aromatic organic compounds.

The leachate contained relatively large aromatic ring systems, naphthalene-like and fluoranthene-like compounds, respectively, as represented by the fluorescence shoulder and peaks around 340 and $390 \mathrm{~nm}$, respectively. To a lesser extent, mono-aromatic ring structures were found in the leachates, based on the low intensities found around $270 \mathrm{~nm}$. It should be noted that what is observed by UV fluorescence spectroscopy is not necessarily the same molecules as those identified by GCMS. In particular, the heavier components, likely containing fused aromatic rings, seen with UV-fluorescence spectroscopy have little chance to pass through the GC column to be detected in GC-MS analysis. The data in Fig. 3 clearly show the presence of complex aromatic ring structures in the leachates.

For biochars, more complex aromatic ring structures were leached into the solution at $\mathrm{pH}$ of 8.5 , as can be 
seen from the small band around $310 \mathrm{~nm}$. While the exact reason remains unclear, the changes in solubility of many organic molecules/structures with $\mathrm{pH}$ must have been at least partly responsible for the observed changes in the fluorescence intensity. In fact, many organic structures such as acidic, phenolic, basic Ncontaining functionalities have higher solubilities in aqueous solutions at higher $\mathrm{pH}$ values. For example, the carboxylic acids, having low solubility in acidic solution, would have increased solubilities at $\mathrm{pH}$ as they are (partly) converted into carboxylates. Possibility also exists that some organic (aromatic) structures could have been oxidised and degraded in strong alkali solutions. The leaching of both organic and inorganic species, possibly exceeding the buffering capacity, changed the $\mathrm{pH}$ of the leaching solution during the leaching process. In particular, the leaching buffer solution with an initial $\mathrm{pH}$ of 3.4 experienced a rapid increase in $\mathrm{pH}$ to values close to or even above 8 . This explains why the final leachate showed an UV-fluorescence intensity close to that for the initial $\mathrm{pH}$ values of 8.5.

The UV-fluorescence data in Fig. 3 are also an indication of the kinetics of the organic matter being leached out of the biochars. The leaching of organics, especially from leaf biochar, was always a slow and gradual process. It appears that the access of water into the micro pores of the biochars as well as the dissolution of organics out of the micro pores in the biochars may have significant activation energy. Alternatively, the leaching of organics involves not only physical process (dissolution and diffusion) but also chemical and/or biochemical reactions (e.g. hydrolysis), which are slow at room temperature. Further research is warranted to understand the nature of the leaching process.

In general, although that bark, leaf and wood biochars are produced under the same conditions, UVfluorescence profiles for these fluidised-bed biochars show that the concentration, nature and kinetics of the leached aromatic organics from biochars depend on the $\mathrm{pH}$ (buffer solution) in which they were leached, and the biochar feedstock.

\section{Conclusions}

A variety of biochars prepared from the pyrolysis of mallee bark, leaf and wood in a fluidised-bed pyrolyser have been leached with aqueous solutions of varying $\mathrm{pH}$ values. The leaching time ranged from $1 \mathrm{~h}$ to 4 weeks.
The initial $\mathrm{pH}$ values of the leaching solutions $(3.4,5.5$, $7,8.5)$ cover the range of the soil $\mathrm{pH}$ in the WA Wheatbelt fields where mallee trees are grown and biochars would be returned. The aim of this study was three-fold: firstly to investigate the potential toxicity due to light bio-oil compounds leached from the biochars. Secondly, to examine the leachability of macronutrients and thirdly, complex organic aromatic compounds, when in contact with different $\mathrm{pH}$ solutions.

The chemical build-up of bark, leaf and bark biochar is different. Although they are produced under similar conditions, they retain different compounds and different concentrations of bio-oil compounds. Phenolics adhered to biochar surfaces have to be considered when added to soils since the biomass species of which they originate will lead to different concentrations in compounds, e.g. phenolics, which could potentially be leached to the soils and/or surrounding waterways. In this study, wood biochars show the largest potential of leaching phenolics to the soil in which it is placed.

The bark, leaf and wood biochar were placed in different $\mathrm{pH}$ solutions showing that the kinetics and concentration of leachable macronutrients and aromatic concentrations will be determined by the biomass feedstock and the buffer capacity of the leaching solution. Biochars liming effect depends largely on the leachability of AAEM to the soil solution; however, there is some evidence of bio-oil compounds, e.g. acetic acid are having an effect on $\mathrm{pH}$ of soil solutions. Since the biochars gave rise to the initial $\mathrm{pH}$ of the leachates, to $\mathrm{pH}$ higher than 8, still the macronutrients and aromatic compounds showed distinct kinetic leaching differences. $\mathrm{K}$ and $\mathrm{Mg}$ are leached gradually with $\mathrm{Mg}$ was more sensitive to $\mathrm{pH}$ than that of potassium. The leaching of $\mathrm{Ca}$ was very minute likely as a result of $\mathrm{Ca}$ being present as $\mathrm{CaCO}_{3}$, insoluble at $\mathrm{pH}>5.8$.

As for the leaching of aromatics together with macronutrients: the leaf biochars gave much higher fluorescence intensity than the wood and bark biochars. The high intensity is either a measure for the concentration and/or polarity of the leached compounds. Further, the UV fluorescence intensity of each leachate seemed to be determined by the $\mathrm{pH}$ of the initial solution, as high intensities were found for leachates with an initial $\mathrm{pH}$ of 8.5. However, the $\mathrm{pH}$ of each of the leaf leachates is above 8 after 4 weeks, seems to indicate that the buffering agents have a bigger effect on the leachability of complex aromatic organic compounds. 
Acknowledgements This project received funding from ARENA as part of ARENA's Emerging Renewables Program and the Second Generation Biofuels Research and Development Grant Program. The study also received support from the Government of Western Australia via the Low Emissions Energy Development Fund and via the Centre for Research into Energy for Sustainable Transport (CREST). This research used large samples of mallee biomass supplied without cost by David Pass and Wendy Hobley from their property in the West Brookton district.

Open Access This article is distributed under the terms of the Creative Commons Attribution 4.0 International License (http:// creativecommons.org/licenses/by/4.0/), which permits unrestricted use, distribution, and reproduction in any medium, provided you give appropriate credit to the original author(s) and the source, provide a link to the Creative Commons license, and indicate if changes were made.

\section{References}

Abdel-Fattah, T. M., Mahmoud, M. E., Ahmed, S. B., Huff, M. D., Lee, J. W., \& Kumar, S. (2015). Biochar from woody biomass for removing metal contaminants and carbon sequestration. Journal of Industrial and Engineering Chemistry, 22, 103-109.

Baker, M. D., \& Mayfield, C. I. (1980). Microbial and nonbiological decomposition of chlorophenols and phenol in soil. Water Air Soil Poll, 13, 1-14.

Bock, R. (1979). A handbook of decomposition methods in analytical chemistry. Glasgow: International Textbook Co.

Buss, W., Graham, M. C., Shepherd, J. G., \& Masek, O. (2016). Risks and benefits of marginal biomass-derived biochars for plant growth. Sci Total Environ, 569-570, 496-506.

Demirbas, A. (2001). Conversion of biomass to a pyrolytic oil for blending gasoline as an alternative fuel in internal combustion engines. Energ Sourc, 23, 553-562.

Demirbas, A. (2005). Pyrolysis of ground beech wood in irregular heating rate conditions. J Anal Appl Pyrol, 73, 39-43.

Djokic, L., Narancic, T., Biocanin, M., Saljnikov, E., Casey, E., Vasiljevic, B., \& Nikodinovic-Runic, J. (2013). Phenol removal from four different natural soil types by Bacillus $\mathrm{sp}$ PS11. Applied Soil Ecology, 70, 1-8.

Fischer, Z., \& Bienkowski, P. (1998). Some remarks about the effect of smoke from charcoal kilns on soil degradation. Environmental Monitoring and Assessment, 58, 349-358.

Focht, U. (1999). The effect of smoke from charcoal kilns on soil respiration. Environmental Monitoring and Assessment, 59, 73-80.

Garcia-Perez, M., Wang, S., Shen, J., Rhodes, M., Lee, W. J., \& Li, C. Z. (2008). Effects of temperature on the formation of lignin-derived oligomers during the fast pyrolysis of Mallee woody biomass. Energ Fuel, 22, 2022-2032.

Gazey, C., \& Andrew, J. (2009). Soil pH in northern and southern areas in the WA wheatbelt. Department of Agriculture and Food, Bulletin 4761.

Ghisalberti, E. L. (1996). Bioactive acylphloroglucinol derivatives from Eucalyptus species. Phytochemistry, 41, 7-22.
Hagner, M., Kemppainen, R., Jauhiainen, L., Tiilikkala, K., \& Setälä, H. (2016). The effects of birch (Betula spp.) biochar and pyrolysis temperature on soil properties and plant growth. Soil Till Res, 163, 224-234.

Hartley, W., Riby, P., \& Waterson, J. (2016). Effects of three different biochars on aggregate stability, organic carbon mobility and micronutrient bioavailability. Journal of Environmental Management, 181, 770-778.

He, M., Mourant, D., Gunawan, R., Lievens, C., Wang, X. S., Ling, K. C., Bartle, J., \& Li, C. Z. (2012). Yield and properties of bio-oil from the pyrolysis of mallee leaves in a fluidised-bed reactor. Fuel, 102, 506-513.

Kashimura, N., Hayashi, J.-I., Li, C.-Z., Sathe, C., \& Chiba, T. (2004). Evidence of poly-condensed aromatic rings in a Victorian brown coal. Fuel, 83, 97-107.

Kershaw, J. R., Sathe, C., Hayashi, J.-I., Li, C.-Z., \& Chiba, T. (2000). Fluorescence spectroscopic analysis of tars from the pyrolysis of a Victorian Brown coal in a wire-mesh reactor. Energ Fuel, 14, 476-482.

Kramer, P. J., \& Kozlowski, T. T. (1979). Physiology of Woody plants. Academic Press Inc: New York.

Lehmann, J. (2007). Bio-energy in the black. Frontiers in Ecology and the Environment, 5, 381-387.

Lehmann, J., \& Joseph, S. (2009). Biochar for environmental management: Science and technology. London: Earthscan.

Lehmann, J., Rillig, M. C., Thies, J., Masiello, C. A., Hockaday, W. C., \& Crowley, D. (2011). Biochar effects on soil biota - a review. Soil Biology and Biochemistry, 43, 1812-1836.

Li, C.-Z., Bartle, K. D., \& Kandiyoti, R. (1993). Characterization of tars from variable heating rate pyrolysis of maceral concentrates. Fuel, 72, 3-11.

Lievens, C., Yperman, J., Vangronsveld, J., \& Carleer, R. (2008). Study of the potential valorisation of heavy metal contaminated biomass via phytoremediation by fast pyrolysis: Part I. Influence of temperature, biomass species and solid heat carrier on the behaviour of heavy metals. Fuel, 87, 1894-1905.

Lievens, C., Carleer, R., Cornelissen, T., \& Yperman, J. (2009). Fast pyrolysis of heavy metal contaminated willow: Influence of the plant part. Fuel, 88, 1417-1425.

Lievens, C., Mourant, D., He, M., Gunawan, R., Li, X., \& Li, C.Z. (2011). An FT-IR spectroscopic study of carbonyl functionalities in bio-oils. Fuel, 90, 3417-3423.

Lievens, C., Mourant, D., Gunawan, R., Hu, X., \& Wang, Y. (2015). Organic compounds leached from fast pyrolysis mallee leaf and bark biochars. Chemosphere, 139, 659-664.

Matsuzawa, Y., Ayabe, M., \& Nishino, J. (2001). Acceleration of cellulose co-pyrolysis with polymer. Polym Degrad Stabil, $71,435-444$.

Mohan, D., Sarswat, A., Ok, Y. S., \& Pittman Jr., C. U. (2014). Organic and inorganic contaminants removal from water with biochar, a renewable, low cost and sustainable adsorbent-a critical review. Bioresource Technology, 160, 191-202.

Mourant, D., Wang, Z., He, M., Wang, X. S., Garcia-Perez, M., Ling, K., \& Li, C.-Z. (2011). Mallee wood fast pyrolysis: Effects of alkali and alkaline earth metallic species on the yield and composition of bio-oil. Fuel, 90, 2915-2922.

Mourant, D., Lievens, C., Gunawan, R., Wang, Y., Hu, X., Wu, L. P., Syed-Hassan, S. S. A., \& Li, C. Z. (2013). Effects of 
temperature on the yields and properties of bio-oil from the fast pyrolysis of mallee bark. Fuel, 108, 400-408.

Oudenhoven, S. R. G., Lievens, C., Westerhof, R. J. M., \& Kersten, S. R. A. (2016). Effect of temperature on the fast pyrolysis of organic-acid leached pinewood; the potential of low temperature pyrolysis. Biomass and Bioenergy, 89, 78-90.

Randolph, P., Bansode, R. R., Hassan, O. A., Rehrah, D., Ravella, R., Reddy, M. R., Watts, D. W., Novak, J. M., \& Ahmedna, M. (2017). Effect of biochars produced from solid organic municipal waste on soil quality parameters. Journal of Environmental Management, 192, 271-280.

Silber, A., Levkovitch, I., \& Graber, E. R. (2010). pH-dependent mineral release and surface properties of cornstraw biochar: Agronomic implications. Environmental Science \& Technology, 44, 9318-9323.

Steiner, C., Das, K. C., Garcia, M., Förster, B., \& Zech, W. (2008). Charcoal and smoke extract stimulate the soil microbial community in a highly weathered xanthic Ferralsol. Pedobiologia, 51, 359-366.

Uchimiya, M., Lima, I. M., Klasson, K. T., \& Wartelle, L. H. (2010). Contaminant immobilization and nutrient release by biochar soil amendment: Roles of natural organic matter. Chemosphere, 80, 935-940.

Uchimiya, M., Wartelle, L. H., Klasson, K. T., Fortier, C. A., \& Lima, I. M. (2011). Influence of pyrolysis temperature on biochar property and function as a heavy metal sorbent in soil. Journal of Agricultural and Food Chemistry, 59, 2501-2510.

Velghe, I., Carleer, R., Yperman, J., Schreurs, S., \& D'Haen, J. (2012). Characterisation of adsorbents prepared by pyrolysis of sludge and sludge/disposal filter cake mix. Water Research, 46, 2783-2794.

Wang, Y., Li, X., Mourant, D., Gunawan, R., Zhang, S., \& Li, C.Z. (2012). Formation of aromatic structures during the pyrolysis of bio-oil. Energ Fuel, 26, 241-247. 